\title{
Mukti Ali's Contributions to Interreligious Harmony in Indonesia
}

\author{
Toguan Rambe \\ Institut Agama Islam Negeri (IAIN) Sidempuan \\ rambetoguan@gmail.com
}

\begin{abstract}
This study explores Mukti Ali's thoughts and contributions to Inter-religious harmony. Thoughts by Mukti Ali were discussed the harmony among religious believers, including comparative religion, the concept of agreeing in disagreement, and inter-religious dialogue, all anchored to the doctrine of Islam rahmat li al-alamin. Mukti Ali pioneered interfaith dialogue as well-known moderate, dialogue, and respect for pluralism, improving justice and peace, understanding each other, and respecting each other within the frame of national unity. Throughout his life, Mukti Ali was known as a staunch Islamic thinker to fight for inter-religious harmony in Indonesia. The whole struggle and contribution in interreligious harmony at least touch some aspects; those are the scientific aspects and social relations. His persistence has a strong theological foundation. Her eagerness Mukti Ali was also known as the father of national harmony in Indonesia.
\end{abstract}

Keywords: Comparative Religion, Mukti Ali, and Religious Harmony

Abstrak. Pemikiran dan kontribusi Mukti Ali terhadap kerukunan antaragama. Pemikiran Mukti Ali membahas tentang kerukunan antarumat beragama, antara lain perbandingan agama, konsep setuju dan tidak setuju, dan dialog antaragama, semuanya bersumber dari doktrin Islam rahmat li al-'alamin. Mukti Ali mempelopori dialog antaragama secara moderat, berdialog, dan menghargai pluralisme, mewujudkan keadilan dan perdamaian, saling memahami, dan saling menghormati dalam bingkai persatuan bangsa. Sepanjang hidupnya, Mukti Ali dikenal sebagai pemikir Islam yang gigih memperjuangkan kerukunan antarumat beragama di Indonesia. Seluruh perjuangan dan kontribusi dalam kerukunan antaragama setidaknya menyentuh 
beberapa aspek; Itulah aspek keilmuan dan hubungan sosial. Kegigihannya memiliki dasar teologis yang kuat. Semangatnya Mukti Ali juga dikenal sebagai bapak kerukunan bangsa di Indonesia.

Kata Kunci: Perbandingan Agama, Mukti Ali dan Harmoni Religius

\section{Introduction}

ne of the discourses that have been rolling for a long time and is
still reaping controversy is inter-religious harmony. The study of
interreligious relations has been much disscussed in Indonesia, and it is time to implement it in social and state life, which are known to be very heterogeneous. This is, because interreligious study is very strategic and contributive in realizing harmonious social interactions and harmony among religious believers to empower the potential and quality of the nation's children. Therefore, the study of inter-religious harmony, and in some cases, have shown an increase, especially in the scientific-academic environment. Continued efforts towards the agreements of language, methodology, and approach in studying religions (religious studies) proved that the cooperation among religious and tradition among religious traditions is not just an issue. Still, it becomes a real choice within the framework of the unity of Indonesia.

The plurality or plurality of mankind is a reality that cannot be avoided (sunnat Allah). Human life is dynamic that it develops multi-nations, cultures, and even differences in beliefs and religions. For Indonesia, plurality is the main characteristic of this beautiful and prosperous country. This diversity can be seen from the aspects of religion, belief, culture, and ethnicity. According to Geertz, it is complicated to determine its exact anatomy. This country is not only multi-ethnic (Malay, Dayak, Kutai, Banjar, Makassar, Bugis, Javanese, Sundanese, Batak, Aceh, Minang, Flores, Balinese, and so on) but also a battleground for various multi-mental and ideological influences (India, China, Holland, Portugal, Hinduism, Buddhism, Confucianism, Islam, Christianity, Capitalism, Socialism, and others (Hardiman, 2002, viii). Because this diversity is like this; some people think that plurality has automatically become an inherent and inseparable part of Indonesian citizens; in this context, the slogan Bhinneka Tunggal Ika is often used as justification.

Especially in the current era of migration and globalization, meetings (contacts) between various ethnic groups, even between religious communities, are more comfortable. Suppose this plurality is adequately maintained and understood. In that case, it will become a potential for the nation and state's development because people help each other provide energy, thoughts, and facilities to support development. The potential for national unity and integrity 
is manifested in socio-political life, economy, arts, government institutions, etc. Because of such a plurality wealth and social capital (social capital) nation and is a source of sublime wisdom that can be adhesive harmonization of social relations binding energy, confounding various elements of a heterogeneous society (Lubis, 2008, 11). In such a context, the growing diversity of religions and cultures has made Indonesia a multicultural, not a monocultural nation. This fact can be potentially positive and negative, depending on how you react.

To direct all the potential for diversity in a positive direction. A serious effort is needed to foster and maintain the condition of a society that promotes the values of harmony and an attitude of tolerance among religious believers. Among the forms of harmony is the willingness of all parties to have a dialogue because dialogue involves the existence of views from one party's positive approach to the other parties. In its order, such dialogue will result in the confirmation of harmony, harmony, and mutual understanding (Hidayat, 1998, 57). In the context of the internal and inter-religious situation in Indonesia, as well as the changing demands of the times, a reformer and a thinker appeared, namely Prof. Dr. H. Abdul Mukti Ali (1923-2004) (Ahmad, ed., 2010, 269-270). Then, called Mukti Ali, who emphasized the importance of proper religious understanding. His obsession was to promote dialogues between religious believers to eliminate suspicion and strengthen knowledge of other religions to foster tolerance of religious differences. Mukti Ali is a scholar of Comparative Religion who has successfully pioneered interfaith relations in Indonesia and fostered enthusiasm among academics to deepen knowledge in this science. $\mathrm{He}$ was named the "father" of comparative religion in Indonesia (Azra, 1998, 286). He was a pluralist thinker who was known to be critical of his traditions. Even though he is a Western alumnus, he is relatively proportional in seeing the issue of Islam-West relations, pluralism, and interfaith relations. Mukti Ali did not stop by merely criticizing, with the spirit of religious studies. He pointed out the variations and developments in the study of interreligious relations, which had a significant role in shaping the pluralist face of Indonesia.

Mukti Ali is very concerned with the problem of inter-religious harmony in Indonesia, which is pluralistic. In the context of the nation's historical conditions, where there are frequent tensions and conflicts between religious believers and driven by his strong scientific instincts. He responds and tries to contribute to this problem by creating and teaching the concept of harmony in life between religious believers with the expression agree in disagreement (Basuki, 2013, 218). This principle is to agree in disagreements based on mutual respect and respect for existing differences, including differences in religious beliefs. This principle completely allows each different religious community to carry out its religious teachings. 


\section{Biography of Mukti Ali}

Mukti Ali is known as a visionary, pluralist, disciplined, and highly respected Muslim intellectual figure. He was born into a fairly well-established family; his father named Idris. However, after he returned from performing the pilgrimage, his name was changed to $\mathrm{H}$. Abu Ali, a person involved in the tobacco business and a person who worked hard and was persistent. While her mother's name was named Muti'ah, and after performing the pilgrimage, it was changed to $\mathrm{Hj}$. Khadidjah, apart from being a housewife, she is also involved in the fabric business. In the establishment of his family Boedjono, the first name of H. A Mukt Ali, was born and raised (Damami, et.al., 1993, 3-5). the owner of 6 siblings was born in Cepu, Blora, Central Java 23 August 1923 (Basuki, 2013, 15).

Discussing Mukti Ali as one of Indonesia's Muslim intellectuals hardly reaps stop. This thinker's charm and charisma, who has six siblings, was born in $\mathrm{Cepu}$, Blora, Central Java, on August 23, 1923 (Basuki, 2013, 15). Mukti Ali is an intellectual who has introduced and developed inclusive Islamic theology. He is also known as a multicultural-plural and democratic warrior, who has an important role in developing Islamic thought, Islamic higher education, interfaith relations, and human values development, with a progressive, inclusive, and pluralist spirit, which makes religious adherents coexist and harmonious. and have a sense of tolerance (Damami, et.al., 37).] These various ideas are conveyed through universities, government officials, discussion forums, seminars, conferences, and writing papers in journal articles and books. Therefore, it is not wrong for Mukti Ali to become an icon of Islamic thought in Indonesia.

As a student, Mukti Ali's Islamic commitment should not be doubted. The background of the original educational environment was the santri in the real sense. Mukti Ali studied Islam at the Islamic boarding school, the Termas Islamic boarding school. He enrolled as a student at STTI (Islamic High School) Yogyakarta with high academic instincts, then he studied in Karachi, Pakistan. In 1955 he was enrolled as a student at the Institute of Islamic Studies, Mc. Gill University, Montreal, Canada, specializing in comparative religion. From here, in fact, it greatly influences the development of Mukti Ali's thought in every scientific discourse discussed because of the Islamic study model at Mc. Gill University uses a systematic, rational, and holistic approach, both in teaching, history, and civilization. This is intended to show that basically, religious traditions can answer modern problems. Regarding the approaching model above, which is the background of Mukti Ali's paradigm of thinking, he provides the following statement:

This kind of approach was also taken by Mas Mansur while teaching 
Islam at the Jakarta Islamic College in 1945. When teaching the interpretation of the al-Qur'an, one of the verses is described in terms of language, then interpreted from a philosophical, historical, legal, economic, social, political perspective according to the situation and conditions of the end the Japanese occupation at that time. The motivation for an Islamic approach like this has not been widely used in Indonesian Islamic Universities. Of course, with strong enthusiasm, it is important to introduce such an empirical or socio-historical approach to the Muslim community in Indonesia to study the treasures of Islamic thought and the context of modernity. Such an approach can make Islam relevant to the context of Indonesian society today and in the future (Ali, 1991, 35).

As a thinker, Mukti Ali was very intensively involved in the struggle of thought. It is known that Mukti Ali's Islamic thought base is rooted in a powerful classical scientific tradition, with a rich combination of insights and treasures of modern thought. Mukti Ali is noted to have organizational activities at home and abroad, government and private, culture, humanity, and science. Various organizational experiences include a member of the Committee on Islamic Culture, based in Paris, a member of the Advisory Council for establishing a Parliament for World Religions in New York, and others (Basuki, 32). Experiences have become a place for Mukti Ali to convey his ideas regarding various matters, including managing relations between religious adherents, which are harmonious and promote peace.

One of Mukti Ali's experiences may be useful to highlight here. When he attended international level religious conferences. These include the IXth history of religion congress in Tokyo, which was held in 1958, the interfaith dialogue held in Beirut in 1970 (on Dialogue between Men of Living Faiths, Beirut: 1970), and the conference held in Kyoto in 197, regarding Religion and Peace (World Conference on Religion and Peace), following Mukti Ali's statement:

One of the things that should be noted after this second world war is the frequency of meetings or congresses of religions between nations. There are religious gatherings that are attended by only religious people, and there are also those who are not religious, as well as experts in nonreligious knowledge. In a religious meeting like the first, which was attended by religious people, it may be driven by the awareness that today's religious people cannot live alone in the religious environment they adhere. They must associate with human groups who embrace other religions. This association method must be considered and pondered together because if tensions, especially conflicts between one 
religious group and another religious group, arise, people can know when the conflict started. Still, people cannot predict when it will end. There was a second nature meeting, which was attended not only by religious experts but also by scientific experts. It seems that it is motivated by the rationality that religion must also talk about world problems and problems faced by mankind, outside the field of religion" (Ali, 1970, 1).

Mukti Ali has often been involved in intellectual debates and in conveying his ideas using a holistic approach since A. Mukti Ali studied Mc. After returning to Indonesia, M. Gill University, Canada. Began to see the seeds of religious reform ideas, especially Islam. To build an Islamic society as desired, a contextual understanding is needed, namely a process of meaning that considers the dynamic interactions between the Islamic teachings that are believed to be and the culture experienced. According to Mukti Ali, there are six methods or approaches that are philological, anthropological, sociological, historical, and apological to obtain an adequate meaning of religion. In its development in the 2oth century, a synthesis of various interrelated sciences was needed in providing interpretations of religion (Ali, 1970, 10). In the future, religious studies results will be even more significant with the cooperation of various social science branches and their methods.

Mukti Ali's character that stands out when conveying his ideas and thoughts is firm but polite, willing to respect others' opinions, not confrontational with those who reject his ideas, tends to seek compromises or middle ground for different views or understandings and is not provocative. When Mukti Ali assumed the post of Minister of Religion, several analyzes stated that the appointment of Mukti Ali to lead the Department of Religion was intended as a measure for the New Order to restructure and reorient policy. With his expertise in religious knowledge and his interests in various inter-religious dialogue forums, Mukti Ali is considered the most competent person to carry out this purpose. Mukti Ali believes that differences in thought, religion, race, ethnicity, language, and culture must guide togetherness in social life. In these differences, all groups must respect and accept plurality as a social reality. This is what, according to Mukti Ali, is very rarely done by the Indonesian people.

Based on these arguments, Mukti Ali intensively develops Comparative Religion Science in Indonesia as a scientific means to create an inclusive attitude, under the term Mukti Ali Agree in Disagreement. Besides, Mukti Ali is full of enthusiasm to cultivate inter-religious dialogue, which is expected to strengthen social harmony. For this reason, the contribution of Mukti Ali's thoughts, which is always consistent in upholding inter-religious harmony in Indonesia, touches at least two aspects, namely the scientific element and social 
relations.

1. Scientific aspects

It is realized that to build dialogue and cooperation between humans. An appropriate method is needed to understand this religious reality. So, in this case, Mukti Ali introduced and developed the discipline of Comparative Religion. His noble obsession in developing the Science of Comparative Religion at IAIN is in the context of arousing interreligious dialogue to eliminate suspicion and find common ground for existing differences. In other words, essential interreligious dialogue must depart from an ethos of mutual respect, a universal humanism view that truly respects humanity, equality of humankind, eliminates egoism, an agreement to accept the truth from others without the tendency to underestimate or distort. In this way, there will be integration between people who are aware of each other's existence and save the world from division. Such is the importance of the Comparative Religion discipline that Mukti Ali gives a quite impressive statement as follows:

"A branch of science that seeks to understand the symptoms of a belief concerning other religions. This understanding includes similarities, as well as differences. From such discussion, the fundamental structure of the religious experience of human life and its importance to that person's life and life will be studied and assessed" (Ali, 7).

Furthermore, according to Mukti Ali, knowledge of other religions will further increase religious differences tolerance. Of course, this discipline is very important, considering that Indonesia is a pluralistic country, including religious diversity. In the context of religion, plurality is part of the anatomy of variety seen from the perspective of society's beliefs. A specific explanation from this perspective shows that this issue is an urgent issue and analytically significant. The role of religion cannot be underestimated in giving birth to the integration of religious communities and social relations. Religion occupies an important place in human life, especially in Indonesia, known as a religious society. The plurality of religions in this area is marked by the diversity of beliefs that are found and at the same time accepted as recognized religions, namely Islam, Christianity, Catholicism, Hinduism, Buddhism, and Confucianism, which are proposed as part of religions that have formal legitimacy to coexist with religions. The fact that Indonesian religions' plurality shows the dynamism and problems faced by the Indonesian people to live side by side in togetherness. So, in terms of understanding religious differences, for example, a person's attitude does not stop at formal understanding but must be understood as a belief and a religious, social reality. They will be tolerant of adherents of other religions. For this reason, it is a sense of consciousness that can provide solutions in humans in religious life. 
It can also be noted that historically-culturally, the Indonesian nation has a religious character because Indonesian culture's growth is very much influenced and colored by religious values and norms (Marzuki, 1981, 9). Therefore, pluralism or pluralism is not only the uniqueness of the Indonesian people. However, in reality, no nation or society is truly single 'unitary' without any elements of difference in it. Supposedly the al-Qur'an as the universal holy book can answer the various problems of Adam's children to establish their caliphate on the surface of this earth, including on interreligious relations (Arifinsyah, 2009, 181). To find out how the al-Qur'an emphasizes religious plurality, several verses provide indications for religious communities' plurality and how to respond to it, among others, Allah. And We had sent down the al-Qur'an to you with the truth, confirming what was before, namely the books (which were revealed before) and the touchstones of the other books; then decide their cases according to what Allah has sent down, and do not follow their passions by leaving the truth that has come to you. For every people among you, We give rules and a clear path. If God wants you, he will make you one person (only), but Allah wants to test you against His gift to you, so be competent to do good. For it is only to Allah that you will all return, and He will tell you what you have disputed about (Q.S. al-Maidah/5: 5).

This verse shows the different paths given by Allah to humans. It is firmly stated that the shari'a of these religions is indeed different. This is perhaps because religion has come down, not a space devoid of history. Religious sharia is usually present as a response to the situation and conditions of the times. Therefore, the diversity of races, nations, tribes, and even differences in space and time necessitate differences in sharia. By contrast, what is meant by contrast is identical to what is commonly termed diversity or plurality, namely the state of some groups in a country or society that have differences. The relation with the science of Comparative Religion is that this science seeks to understand all aspects obtained from the study of the history of religion and then seriously link or compare one religion with another to achieve and determine the fundamental structure of experiences and conceptions by selecting and analyze the similarities and differences between the religions. Comparison of religion comparing religion and its methods to achieve a goal. Thus, comparative religion is a branch of science that seeks to investigate and understand the religious aspects or attitudes of a belief to other religions, including similarities and differences. This fact is found in a pluralistic society.

Based on the explanation above, regarding the urgency of comparative religion in the midst of such a pluralistic life, perhaps to anticipate or minimize the potential for conflicts between religious communities in Indonesia, it is deemed necessary to publicize Mukti Ali's bright ideas. As an intellectual who is 
very concerned about the harmony of life between religious communities in Indonesia, which is pluralistic, he has also landed the concept of agree in disagreement, in the context of the nation's historical situation and conditions where tensions and conflicts often occur, as well as the order of harmony among religious communities in Indonesia which often experiences tides. Retroactive, it requires a principle that raises an attitude of respect and respect for all existing differences. Even Amin Abdullah said that the concept of agree in disagreement, which Mukti Ali put forward, was very Qur'an and had pluralistic values (Abdullah, 1995, 73). It's hoped that these ideas and concepts are very urgent to be implemented in a plural society.

2. Social Relations

Mukti Ali added that to create harmonious social relations. It's important to cultivate and carry out interreligious dialogue, hoping that tolerance will foster interreligious relations in Indonesia, which is very plural. Furthermore, Mukti Ali explained that the dialogue was held not solely for the dialogue itself but also to increase the Indonesian people's harmony and welfare (Basuki, 26o). Mukti Ali's struggle to create national stability so that national development can run smoothly is his concept to achieve harmony between religious believers. The concept is widely known, namely agree in disagreement, which is usually defined as agree on differences. Regarding the understanding of this concept, he further elaborates as follows:

"The Indonesian nation is currently developing towards a whole human being in a 'plural society', a versatile society, both in faith, religion, language, and culture. Religious Indonesians are required to be harmonious in religious life. Unrest in religious life is an obstacle to development. Development is impossible in a chaotic society. The harmony of community life is a pre-condition for development. Pillar in religious life can be created if each person is tolerant and tolerant (Indonesian-Netherlands Cooperation in Islamic Studies, 1992, 229).

The Indonesian nation was born from a long and unique path. This nation comprises various races, various local cultures, customs, religions, and religions, all of which naturally contain differences. However, in the history of the formation of the Indonesian nation, the differences did not diminish and became a barrier to unity. One of the interesting invitations to strengthen our Indonesian solidity is to ground the four pillars of national life: Pancasila, UUD 1945, NKRI, and Bhinneka Tunggal Ika treasures modalities of the Indonesian nation (Arifinsyah, 2013, 95-100). It's realized that the national construct through these four pillars will bridge the gap between interests and, at the same time, irrigate and strengthen our Indonesian nationality. The significance of this national project also finds momentum when efforts to improve itself for 
Indonesia are increasingly being felt and, on the other hand, supported by all levels of Indonesian society. As a thinker and observer of religious plurality, Mukti Ali also comments on the diversity or plurality of the Indonesian nation, as follows:

"The Indonesian country keeps a variety of diversity and diversity. This plurality and diversity manifest in various aspects of the Indonesian nation's life, which occupies thousands of islands in one vast area. The Indonesian country is composed and formed by multiple ethnic groups who have their customs and languages besides adhering to different religions. Therefore, it is inevitable that people's values and lives are not the same, let alone one (Ali, 1987, 321).

According to Mukti Ali, there are two foundations for fostering religious harmony in Indonesia. First, it is philosophical in the form of Pancasila's state philosophy, which invites basic values and principles that can be accepted by all parties and groups. The second is pragmatic, namely the national task in the nation-building framework where all parties are obliged to carry out and make it a success (Ali, 1972, 113). The Indonesian nation consists of various ethnicities, cultures, languages, religions, levels of education, economic life, and so on. This plurality can be a positive potential when it becomes a motivation for healthy competition to gain progress. On the other hand, plurality becomes negative when it turns into a potential that can ignite mutually destructive conflicts and enmities (Ali, 1972, 113). Moreover, if the conflict occurs in matters of religious belief, the problem will be even more complex because it will disturb social harmony and injure national harmony.

It cannot be denied that wars and violence have marred the long history of Indonesia's religious development. As a pluralist and multicultural country, with various religions, various cultures, ethnicities, languages, this plurality, on the one hand, is one of the riches of the nation, which is quite encouraging, but on the other hand, if this plurality and diversity cannot be managed properly, it will become a conflict that can divide the destiny of this nation. There are several records of conflicts and violence in the name of religion in Indonesia (Kompas, $15 / 10 / 2015,22)$. This can be seen from the results of a survey conducted by several institutions, including CRCS UGM, Wahid Institue, which stated that the number of religious-based violence and discrimination against minority sects and religions, whether perpetrated by individuals, groups, or social and religious organizations, is increasing.

If religious believers prefer the path of violence and conservatism in character, then this choice will result in hostility, catastrophe, and close the creation of dialogue. Therefore, a humanist and open dialogue built based on a broad view is urgent. According to Mukti Ali, all religions are urged to think of 
practical attitudes to interact with other religions but are also encouraged to understand theologically what the meaning of other religions and beliefs means (Arifinsyah, 151). Because dialogue is a forum for encounters between human children that can dissolve various authoritarian attitudes and eliminate mutual suspicion between fellow religious communities. People who are anti-dialogue in the context of life today are like people who want to carry heavy burdens alone, even though those burdens become light when taken together. Because human life always shows its plurality and plurality, especially from a religious point of view. As a logical consequence of this fact, all religions regulate interfaith interactions within the framework of plurality harmony or pluralistic harmony (Harahap, 2011, 98).

Humanity on this earth must be united in the frame of humanity. Islam is a religion that carries a noble mission, namely, rahmatan li al-'alamin. According to Andreas, interfaith cooperation is a continuation of the agenda of religious dialogue (Yewngoe, 2009, 247-248). Cooperation, which is termed cooperation, is an inseparable part of the dialogue. Every religious community should not be shackled only in their religion. They must go out and interact with followers of other religions. It is through human values that every human child is brought together (Siraj, 2006, 234). It is not surprising that the theologian and religious dialogue activist, Hans Kung, stated with great confidence that "there is no world peace if there is no religious peace (Kung, 1991, xv). Kung suggests that peace can only be realized through dialogue and cooperation, carried out correctly and consistently. Intimacy in building cooperation like this cannot be separated from a sincere attitude in religion. This attitude requires every religious adherent to give the best for humanity without expecting anything in return. A religious adherent to another religion can have deep emotional ties; the main factor is sincerity (Maarif, 2009, 272).

Differences in faith are not a barrier to joining two hearts of human beings with different beliefs. Therefore, without religious sincerity, the cooperation built by adherents will feel dry and exist only at the physical level (Maarif, 2009, 272). For this reason, it is deemed necessary to adopt and apply this concept to create national stability so that it can run smoothly through the harmony of the life of religious communities. It's difficult for the Indonesian nation to carry out development programs to obtain a prosperous life if conditions of harmony between religious believers have not been maintained. Therefore, the principle of agree in disagreement, interfaith dialogue, and the urgency of comparative religious disciplines, embodies the spirit of Bhinneka Tunggal Ika in realizing harmony in the life of religious communities in Indonesia. 


\section{Conclusion}

A complete picture of Mukti Ali's conception of thought in discussing the discourse of religious harmony includes Comparative Religion, the concept of agree in disagreement, and interreligious dialogue. Entirely based on Islamic doctrine as rahmatallil' alamīn. His thinking through comparative religion science certainly provides a high scientific spirit because it comprehensively approaches religion. So, create a dynamic religious lifestyle; the concept of agree in disagreement is a firm principle in the reality of religious plurality. The concept combines a vision of divinity with humanity, the same as the concept of the Trilogy of Harmony. To land this idea, Mukti Ali pioneered interfaith dialogue, known for being moderate, dialogic, and respecting pluralism. He developed in Higher Education, and when he served as Minister of Religion (1971-1978). Mukti Ali's thoughts in upholding interreligious harmony in Indonesia touch at least two aspects: the scientific and social relations.

In the aspect of knowledge characterized the appearance of comparative religions as a science that is so important to understand and respond to the diversity of religions. Also, as a means of creating dynamic interactions between religions. Meanwhile, contributing to social relations is reflected in the concept which is full of the meaning of agree in disagreement and interreligious dialogue as an effort to create a spirit of cooperation between religious believers, the realization of internal and inter-religious harmony within the nation. Based on these two aspects, it is hoped that human behavior in social life will be based on the spirit of brotherhood and a sense of justice. As an intellectual in Indonesia, Mukti Ali emphasizes that this principle should be used by religious communities to regulate and foster a society following the demands of the everchanging times. Mukti Ali's thoughts and ideas regarding inter-religious harmony are needed in the current era of globalization, not only in Indonesia but also in the world. However, the brilliant ideas he promoted were limited to his basic concepts, through the results of reflections on his time's social reality. The methodological instruments or completeness and the application of their thoughts still require further elaboration, especially from future generations. However, Mukti Ali has contributed to a contributive idea regarding the basic concept of inter-religious harmony with all his strengths and weaknesses. With that thought, it has enriched the treasures of Islamic thought.

\section{References}

Abdullah, M. Amin, 1995. "Islam Indonesia Lebih Pluralistik dan Demokratis", Ulumul Qur'an, 3 (6).

Ali, A. Mukti, 1972. Agama dan Pembangunan di Indonesia, Jakarta: Biro Hubungan Masyarakat, Depertemen Agama Republik Indonesia. 
Ali, A. Mukti, 1987. Berbagai Persoalan Agama Dewasa Ini, Jakarta: Rajawali.

Ali, A. Mukti, 197o. Dialog antar Agama, Yogyakarta: Yayasan Nida.

Ali, A. Mukti, 1965. Ilmu Perbandingan Agama: Sebuah Pembahasan tentang Metode dan Sistem, Yogyakarta: Yayasan Nida.

Ali, A. Mukti, 1991. Metode Memmahami Agama Islam, Jakarta: Bulan Bintang. Arifinsyah, 20o9. Dialog Global Antaragama: Membangun Budaya Damai dalam Kemajemukan, Bandung: Citapustaka Media Perintis.

Arifinsyah, 2013. FKUB dan Resolusi Konflik: Mengurai Kerukunan Antarumat Beragama di Sumatera Utara, Medan: Perdana Publishing.

Azra, Azyumardi, ed., 1998. Menteri-Menteri Agama RI: Biografi Sosial-Politik, Jakarta: Seri INIS.

Basuki, Singgih, 2013. Pemikiran Keagamaan A. Mukti Ali, Yogyakarta: Suka Press.

Damami, M. et.al., 1993. "H. A. Mukti Ali: Ketaatan, Kesalehan dan Kecendekiaan", Abdurrahman, et.al. ed., 7o Tahun H. A Mukti Ali Agama dan Masyarakat, Yogyakarta: IAIN Sunan Kalijaga Press.

Departemen Pendidikan dan Kebudayaan, 1988. Kamus Besar Bahasa Indonesia, Jakarta: Balai Pustaka.

Harahap, Syahrin, 2011. Teologi Kerukunan, Jakarta: Prenada Media Group.

Hardiman, F. Budi, 2002. "Pengantar Belajar dari Politik Multikulturalisme", Will Kymlicka, Kewargaan Multikultural, Jakarta: Pustaka LP 3 ES Indonesia.

Hidayat, Komaruddin, 1998. Melintasi Batas Agama, Jakarta: PT Gramedia Pustaka Utama.

Indonesian-Netherlands Cooperation in Islamic Studies, 1992. Ilmu Perbandingan Agama di Indonesia dan Belanda: Kumpulan Makalah Seminar, Jakarta: INIS.

Kung, Hans, 1991. Global Responsbility: In Search of A New World Ethic, New York: Cross Road.

Lubis, Nur Ahmad Fadhil, 20o8. "Multikulturalisme dan Persinggungannya dengan Agama dan Umat Islam", Jurnal Kerukunan Berbasis Multikultural, 2 (1).

Maarif, Ahmad Syafii, 20og. Islam dalam Bingkai Keindonesiaan dan Kemanusiaan: Sebuah Refleksi Sejarah, Bandung: Mizan.

Marzuki, Ahmad, 1981. Pembinaan Kehidupan Beragama dalam Masyarakat untuk Mensukseskan Pembangunan, Jakarta: Departemen Agama.

Rahardjo, M. Dawam, 2010. "Pembaruan Pemikiran Islam, Sebuah Catatan Pribadi", Saidiman Ahmad, ed., Pembaharuan tanpa Apologia: Esai-esai tentang Ahmad Wahib, Jakarta: Yayasan Wakap Paramadina.

Siraj, Said Aqil, 20o6. Tasawuf sebagai Kritik Sosial: Mengedepankan Islam sebagai Inspirasi, Bukan Aspirasi, Bandung: Mizan.

Tim FKUB Sumatera Utara, 20og. "Kerangka Acuan: Dialog Urgensi Aktualisasi 
Journal of Islamic Thought and Muslim Culture (JITMC), 2 (1), 2020|47

Pendidikan Multikultural dalam Membangun Kerukunan Antar Umat Beragama", Makalah, Seminar Dialog Urgensi Aktualisasi Pendidikan Multikultural dalam Membangun Kerukunan Antar Umat beragama, di Medan, 17 Oktober.

Yewngoe, Andreas Ananguru, 20og. Tidak Ada Penumpang Gelap, Jakarta: BPK Gunung Mulai. 